\title{
Konsep Sistem Informasi Akreditasi Perguruan Tinggi Berbasis Cloudcomputing
}

\author{
Sulfikar Sallu ${ }^{1}$, Darlispon ${ }^{2}$ \\ ${ }^{1}$ Program Studi Teknik Informatika, Fakultas Teknik Universitas Maritim Raja Al Haji \\ ${ }^{2}$ Program Studi Teknik Informatika, STIKOM Muhammadiyah Batam \\ Email: info.sulfikarsallu@gmail.com
}

\begin{abstract}
ABSTRAK
Akreditasi perguruan tinggi adalah bentuk pengakuan pemerintah berupa penilaian terhadap lembaga penyelenggara pendidikan tinggi yang meliputi semua aspek yang ada berdasarkan standar nasional pendidikan tinggi, dalam menunjang proses belajar. Akreditasi ini dilaksanakan oleh Badan Akreditasi Nasional Perguruan Tinggi yang dibentuk pemerintah. Banyaknya persiapan data yang diperlukan untuk pelaksanaan Akreditasi perguruan tinggi yang hampir sebagian besar masih menggunakan cara manual atau semi komputerisasi yang tidak saling terhubung, merupakan sebuah kondisi yang masih terjadi sekarang ini. Tahapan yang akan dilakukan adalah mengumpulkan seluruh dokumen yang ada dalam akreditasi perguruan tinggi untuk dikonversi berbasis elektronik. Tujuan penelitian ini adalah merancang sistem informasi akreditasi perguruan tinggi berbasis cloudcomputing yang akan memudahkan komunikasi ilmiah antara perguruan tinggi dengan asesor dalam pengolahan data. Metode penelitian yang digunakan adalah importif terapan, langkah ini diambil untuk menerapkan, menguji dan mengevaluasi kondisi yang ada berkenaan dengan penemuan dan pengembangan ilmu dalam memudahkan sistem akreditasi perguruan tinggi sekarang ini, semua yang akan terlibat dapat melaksanakan tugas masing-masing dimana dan kapan saja, adapun hasil yang ingin dicapai pada penelitian ini adalah memudahkan perguruan tinggi dalam menyiapkan data akreditasi yang telah terkoneksi dengan sistsm informasi kampus dan juga memudahkan asesor dalam pelaksanaan tugas.
\end{abstract}

Kata kunci: Sistem Informasi Akreditasi Perguruan Tinggi, Cloudcomputing

\begin{abstract}
College accreditation is a form of government recognition in the form of an assessment of the provider institution of higher education that covers all aspects of the existing under national standards of higher education, in supporting the learning process. Accreditation is carried out by the National Accreditation Board of Higher Education established by the government. The number of data preparation required for implementation of the accreditation colleges that almost most still use manual or semi computerized unconnected, a condition that still occurs nowadays. The milestones is collect all the documents that exist in the accreditation of the universities to convert electronic based. The purpose of this study is to design information systems based college accreditation cloudcomputing that will facilitate scientific communication between universities and assessors in data processing. Methods used are importif applied, this step was taken to implement, test and evaluate existing conditions with respect to the discovery and development of science in facilitating the accreditation system of higher education today, all of which will be engaged to carry out their respective tasks anytime and anywhere, the results to be achieved in this research is to facilitate the college in preparing the accreditation of data that has been connected with sistsm campus information and also facilitate the assessors in the execution of tasks.
\end{abstract}

Keywords: College accreditation information system, Cloud computing 


\section{LATAR BELAKANG}

Sistem Pendidikan Indonesia menganut beberapa sistem pendidikan mulai pendidikan dasar, pendidikan menengah dan pendidikan tinggi. Selanjutnya sistem pendidikan menganut beberapa sistem yang serung dijumpai antara lain: (a) sistem pendidikan yang berorientasi nilai, sistem pendidikan ini memberikan pengetahuan dan pengajaran peserta didik dalam kejujuran, tenggang rasa, disiplin dan sejenisnya (b) sistem pendidikan beragam, sistem pendidikan ini menggunakan metode sesuai dengan suku, daerah, budaya, tradisi (c) sistem pendidikan terbuka, sistem pendidikan ini menuntut peserta didik untuk bersaing dengan teman, berfikir kreatif dan inovatif (d) sistem pendidikan perubahan zaman, sistem pendidikan yang harus menyesuaikan deng an kutikulum (e) sistem pendidikan efisiensi dalam pengelolaan waktu, sistem pendidikan ini mengatur waktu sedemikian agar peserta didik tidak merasa terbebani dengan materi yang disampaikan.

Sistem Pendidikan Perguruan Tinggi di Indonesia terdiri dari Pendidikan akademik yang memiliki fokus dalam penguasaan ilmu pengetahuan dan pendidikan vokasi yang menitik beratkan pada persiapan lulusan untuk mengaplikasikan keahliannya. ${ }^{[1]}$ Adapun rincian perguruan tinggi adalah: Perguruan Tinggi Akademik 1081, Politeknik 229, Sekolah Tinggi 2360, Institut 121 dan Universitas 517. Total Perguruan Tinggi 3791 berdasarkan data yang di ada di Forlap.Menurut undang-undang no.12 tahun 2012 pasal 65 ayat 1 : Penyelenggaraan otonomi perguruan tinggi sebagaimana dimaksud dalam pasal 64 dapat diberikan secara selektif berdasarkan evaluasi kinerja oleh menteri kepada PTN dengan menerapkan pola pengelolaan keuangan badan layanan umum atau dengan membentuk PTN badan hukum untuk menghasilkan pendidikan tinggi bermutu. Dalam Peraturan Pemerintah Republik Indonesia nomor 42014 tentang Penyelenggaaraan Pendidikan Tinggi dan Pengelolaan Perguruan Tinggi dalam Bab 1 Pasal 1 point 6 : Perguruan Tinggi Swasta yang selanjutnya disebut PTS adalah Perguruan Tinggi yang didirikan dan atau diselenggaran oleh masyarakat. Pemerintah telah memberikan aturan yang cukup jelas terhadap pengelolaan perguruan tinggi, baik perguruan tinggi negeri (PTN) maupun pergutruan tinggi swasta (PTS) di Indonesia. Masing-masing perguruan tinggi itu memiliki fungsi yang jelas sesuai dengan UU no. 12 tahun 2012 pasal 4 yaitu: (1) mengembangkan kemampuan dan membentuk watak serta peradaban bangsa yang bermartabat dalam rangka mencerdaskan kehidupan bangsa (2) mengembangkan sivitas akademika yang inovatif, responsif, kreatif, terampil, berdaya saing dan kooperatif melalui pelaksanaan Tri Darma dan (3) mengembangkan ilmu pengetahuan dan teknologi dengan memperhatikan dan menerapkan nilai humaniora.

Banyaknya perguruan tinggi serta tidak meratanya pembangunan infrastuktur dan sumber daya menjadi salah satu penyebab banyaknya perguruan tinggi yang tidak memiliki standar kualitas seperti yang diharapkan.

Kualitas Pendidikan Tinggi di Indonesia jauh tertinggal ${ }^{[2]}$ dari segala sisi, antara lain kualitas alumni (tidak memiliki sertifikasi keahlian standart internasional) dan publikasi ilmiah (sebagai salah satu indikator kualitas pendidikan tinggi di dunia). Menteri menjelaskan bahwa kunci memenangkan persaingan itu adalah peningkatan kualitas kelembagaan dan sumber daya manusia (SDM) sehingga melahirkan karya-karya inventif, inovatif yang bermanfaat bagi masyarakat serta terus melakukan pengembangan ilmu pengetahuan dan menghasilkan lulusan yang berdaya saing tinggi.

Setelah mengamati sistem pendidikan di Indonesia maka ada tiga masalah pokok yang dihadapi pengelola pendidika antara lain: (1) pemerataan pendidikan, kondisi yang ada perguruan tinggi yang lumayan bagus hanya dapat dinikmati oleh kalangan menengah keatas (2) biaya pendidikan, keadaan indonesia terpuruk berdampak pula pada pendidikan di Indonesia, karena biaya pendidikan tinggi yang mahal. (3) kualitas pendidikan banyak tenaga pengajar yang mengajar tidak sesuai dengan bidangnya dan tingkat kejujuran serta kedisiplinan peserta didik yang masih rendah. 
Pemerintah dalam hal ini Dinas Pendidikan melalui Badan Akreditasi Nasional Perguruan Tinggi (BAN-PT) ditunjuk untuk melaksanakan Akreditasi. Akreditasi Pendidikan Tinggi terutama program studi sebagai bagian dari perguruan tinggi yang langsung berinteraksi dengan mahasiswa adalah proses evaluasi dan penilaain secara komprehensif atas komitmen program studi terhadap mutu dan kapasitas penyelenggaraan tridarma perguruan tinggi untuk menentukan kelayakan program akademiknya. Selanjutnya BAN-PT yang memiliki kewenangan untuk mengevaluasi dan menilai serta menetapkan status peringkat mutu program studi berdasarkan standar mutu yang telah ditetapkan. karena kurang pengawasan dalam pengelolaannya sejak awal berdirinya maka banyaknya kampus yang di-nonaktifkan.

\section{METODOLOGI PENELITIAN}

\subsection{Kajian Literatur dan Pengembangan}

Standar Akreditasi adalah tolak ukur yang harus dipenuhi program studi diploma, standar akreditasi ini terdiri atas beberapa parameter (indikator kunci) yang dapat digunakan sebagai dasar (1) penyajian dan informasi mengenai kinerja, keadaan dan perangkat pendidikan program studi diploma yang dituangkan dalam insrrumen akreditasi (2) evaluasi dan penilain mutu kinerja keadaan dan perangkat pendidikan program studi diploma (3) penetapan kelayakan program studi diploma untuk menyelenggarakan program-programnya dan (4) perumusan rekomendasi perbaikan mutu dan program diploma. ${ }^{[3]}$ Hal inilah yang menjadi parameter yang mesti dipenuhi setiap program studi untuk memperoleh hasil yang maksimal.

Cloudcomputing adalah gabungan pemanfaatan teknologi komputer berbasis pengembangan internet yang saling terhubung. Kemunculan cloudcomputing memberikan nilai tambah bagi perancangan arsitektur teknologi informasi untuk organisasi termasuk institusi pendidikan. ${ }^{[4]}$

Berikutnya adalah Penjaminan mutu sebagai hasil akreditasi yang dilakukan, dalam tujuan penjaminan mutu eksternal atau akreditasi adalah (1) menentukan kelayakan program studi dan perguruan tinggi berdasarkan kriteria yang mengacu pada standar nasional pendidikan tinggi (2) menjamin mutu program studi dan perguruan tinggi secara eksternal baik bidang akademik maupun non akademik untuk melindungi kepentingan mahasiswa dan masyarakat. ${ }^{[5]}$ Selanjutnya program studi juga perlu menjaga mutu dari hasil akreditasi yang telah dilakukan. Diharapkan sebuah Institusi Perguruan Tinggi wajib (1) menguasai, memanfaatkan, mendiseminasikan, mentransformasikan dan mengembangkan ilmu pengetahuan teknologi dan seni (ipteks) (2) mempelajari, mengklarifikasi, dan melestasrikan budaya serta (3) meningkatkan mutu kehidupan masyarakat. ${ }^{[6]}$

\subsection{Metode dan Tahapan Penelitian}

Dalam proses pelaksanaan akreditasi ini ada beberapa hal yang menjadi substansi yang diatur antara lain: (1) Instrumen akreditasi perguruan tinggi (2) Instrumen akreditasi program studi (3) masa berlaku akreditasi (4) status akreditasi (5) akreditasi ulang (6) keberatan atas status akreditasi (7) pembentukan tugas, organisasi BAN PT dan (8) Pengangkatan dan Pemberhentian anggota BAN-PT.

Dalam proses akreditasi yang diadakan selama ini terdapat beberapa kendala yang sering dihadapi antara lain : (1) Anggota Tim Yang Kurang Cakap (2) Data Menyebar sehingga sulit dikumpulkan (3) DayaBase yang jelek (4) Sulit mengumpulkan anggota tim dan (5) Penulisan tidak mengacu pada standar Penilaian. ${ }^{[7]}$ Selanjutnya ada beberapa komponen yang dilibatkan dalam pelaksanaan akreditasi ini yaitu : Lembaga Pendidikan yang akan di akreditasi, BAN-PT sebagai pelaksana kegiatan akreditasi, asesor sebagai orang yang ditugaskan oleh BAN-PT untuk melakukan penilaian lembaga 
pendidikan.Metode yang digunakan sekarang ini dalam melakukan akreditasi perguruan tinggi maupun program studi masih menggunakan cara konvensional (manual).

Perkembangan penerapan teknologi yang juga diikuti dengan perkembangan sistem informasi telah membawa perubahan yang sangat membantu dalam proses pengolahan data. Sistem Informasi Akreditasi Kampus akan melakukan semua konversi data manual yang ada dalam buku panduan akreditasi menjadi data digital. Cara kerja sistem ini adalah: (1) Perguruan Tinggi melakukan pengisian Data Digital (2) BAN PT sebagai lembaga yang memiliki wewenang dalam melakukan akreditasi memantau kelengkapan data yang dimasukkan oleh Perguruan Tinggi (3) Asesor dapat melakukan penilaian secara online (kapan dan dimanapun, selama masa waktu penilaian) terhadap dokumen yang dimasukkan oleh perguruan tinggi dan telah di setujui oleh BAN-PT (4) Saat kunjungan ke Perguruan Tinggi asesor hanya tinggal melakuakn validasi data berdasarkan dokumen yang telah dimasukkan kedalam sistem. Dalam sistem informasi ini, semua penilaian asesor akan langsung dapat menampilkan hasil, sehingga akan langsung menampilkan nilai secara transparansi, sistem informasi ini juga dilengkapi dengan history setiap perubahan yang terjadi serta dokumentasi digital. Selanjutnya sistem keamanan yang ada menggunakan pembagian akses yang terdiri dari: user hak akses ini hanya dapat melihat data, admin hak akses ini hanya bisa untuk memasukkan data perguruan tinggi dan asesor hak akses ini hanya digunakan unruk melakukan penilaian. Setelah login, maka pengguna sistem informasi dapat melakukan aktifitasnya sesuai dengan hak akses yang dimiliki.

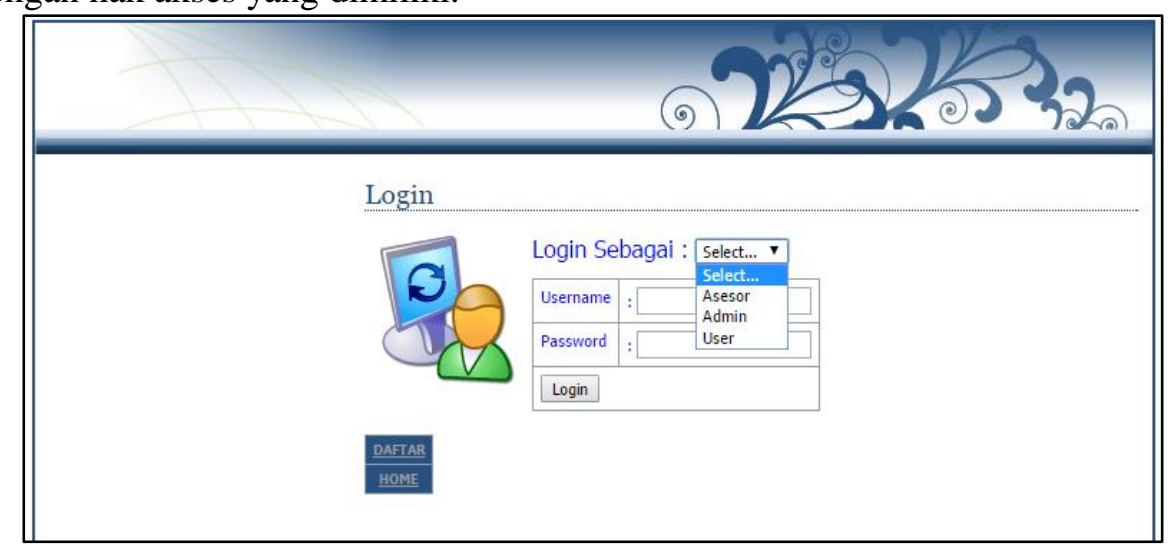

Gambar 1. Tampilan Login

\section{ANALISIS DAN PEMBAHASAN}

Cloudcomputing merupakan perkembangan teknologi informasi dari sebuah revolusi komputer, cloudcomputing dapat dijadikan menjadi sebuah standart yang dapat di implementasikan pada sebuah lembaga penyelenggara akreditasi. Sistem Penilaian akreditasi yang dilaksanakan selama ini memerlukan waktu dan masa tunggu hasil yang agak lama dan salah satu penyebabnya adalaha banyaknya perguruan tinggi dan sebaran antara pulau satu dengan pulau lain. Penggunaan cloudcomputing mulai cocok diterapkan lembaga setingkat BAN-PT karena teknologi dan komputasi yang berbasis cloud, dinilai memberikan kemudahan dan keuntungan dimana pengguna (perguruan tinggi, BAN-PT dan asesor) karena hanya melakukan instalasi sistem operasi secara online dan dapat menggunakan aplikasi sistem informasi akreditasi kampus seauai yang dibutuhkan tanpa terlebih dahulu meng instal dikomputerterlebih dahulu atau perangkat elektronik yang dapat terhubung ke internet. Masing-masing perguruan tinggi dan asesor hanya membutuhkan koneksi ke Internet. BAN-PT dalam hal ini hanya mengawasi proses akreditasi yang dapat berlangsung secara online. Waktu kunjungan juga menjadi singkat (efisiensi waktu kerja) dan tugas asesor juga menjadi lebih mudah (hanya melakukan 
validasi data, karena sebelumnya telah melakukan penilaian online) serta mempersingkat (waktu tunggu) informasi hasil yang akan diperoleh oleh Perguruan Tinggi.

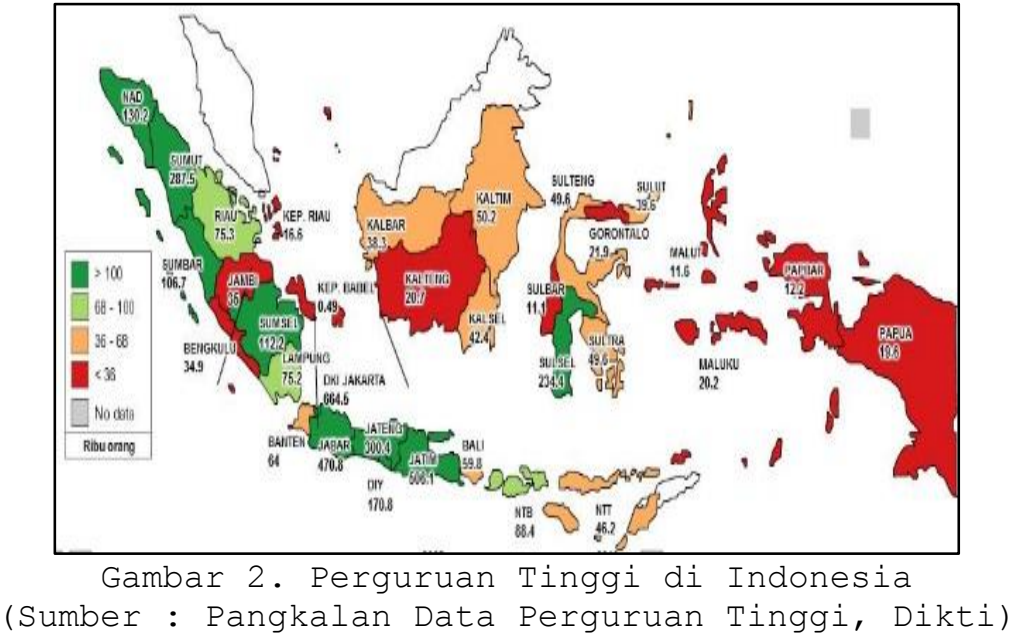

Banyaknya jumlah serta penyebaran lokasi perguruan tinggi, tidak lagi menjadi permasalahan yang akan dihadapi. Jika mengalami kondisi terburuk maka perguruan tinggi dapat melakukan pemasukan dan validasi data pada kota terdekat. Seluruh wilayah Indonesia telah hampir fasiltas teknologi internet. Selanjutnya penggunaan sistem informasi ini akan dapat mengkonversi seluruh data yang selama ini dikerjakan manual, menjadi data digital, adapun langkah pengembangannya adalah (1) menciptakan aplikasi sistem informasi akreditasi ini (2) mempersiapkan saran dan prasarana pendukug yang diperlukan antara lain: infrastructure as a service (IassS), platform as service (PasS) dan Software as service (SaaS) (3) melakukan kerjasama antara penyedia layanan dengan dinas terkait seperti contoh aplikasi tampilan berikut ini yang menampilkan admin perguruan tinggi dalam memasukkan data.

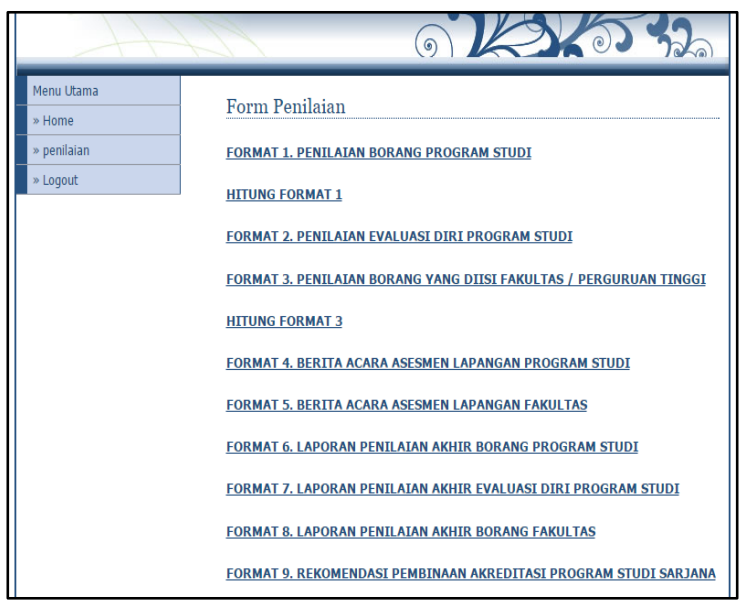

Gambar 3. Form Penilaian

Form diatas merupakan form yang merupakan tampilan yang sebelumnya menggunakan data excel yang terdiri dari: borang program studi, evaluasi diri program studi, borang yang diisi fakultas / perguruan tinggi, berita acara asesmen lapangan program studi, berita acara asesmen lapangan fakultas, laporan akhir borang program studi, laporan penilaian akhir evaluasi diri program studi, lapoaran akhir penilaiain borang fakultas dan rekomendasi pembinaan akreditasi program studi.berikutnya admin melakukan pengisian data sebagai berikut: 


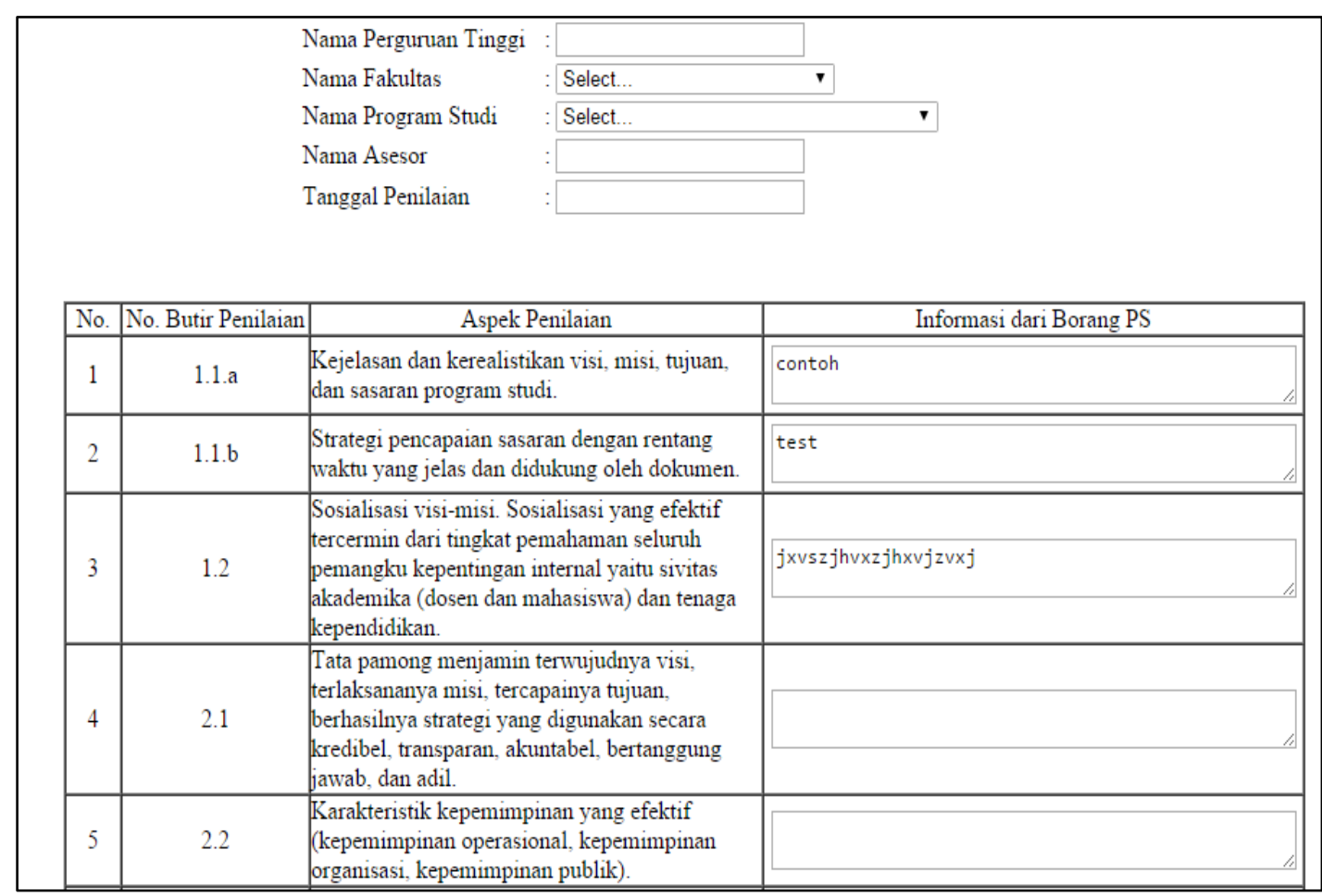

Gambar 4. Form Isian Data Penilaian Borang Program Studi

Sistem informasi akreditasi kampus akan menyimpan seluruh transaksi pengolahan data. Pada login ini admin hanya bisa menuliskan dan melakukan upload dokumen sesuai yang dipersyaratkan. Berikutnya adalah login sebagai asesor, pada bagian ini, hanya mampu melakukan penilain dan melihat data dan dokumen yang telah di upload oleh admin perguruan tinggi, berikut tampilannya:

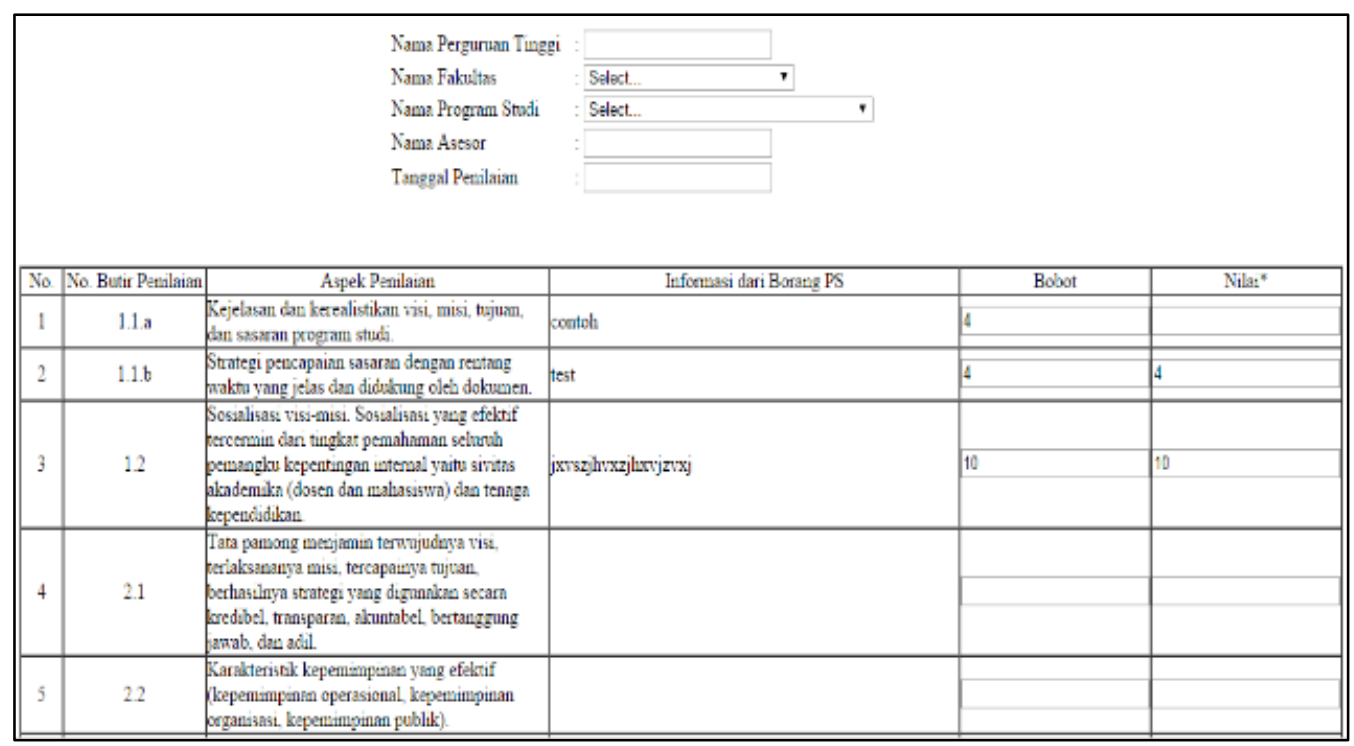

Gambar 5. Form Penilaian Data Penilaian Borang Program Studi

Berikutnya adalah Form Penilaian online oleh asesor yang akan menilai seluruh dokumen yang telah di masukkan maupun di upload. Pada login ini setiap asesor hanya diperbolehkan oleh sistem informasi akareditasi kampus memberikan penialain dan melakukan download dokumen, adapun jumlahnya dikerjakan langsung oleh sistem informasi ini. 


\section{KESIMPULAN}

Kendala-kendala yang dihadapai perguruan tinggi maupun program studi dapat sedini mungkin dikurangi karena dengan menggunakan sistem informasi ini dapat melakukan simulasi sesuai dengan data yang ada. Banyak perguruan tinggi / program studi yang mengalami kesulitan dalam penyiapan borang akreditasi. Perkembangan Teknologi Informasi dapat di implementasikan dalam melakukan alreditasi kampus, sehingga semua pihak akan dapat merasakan manfaat dan kegunaan yang positif dari teknologi informasi itu.

\section{DAFTAR RUJUKAN}

[1] Website Dinas Pendidikan Tinggi, Sistem Pendidikan Tinggi, http://dikti.go.id/profildikti/sistem-pendidikan-tinggi/, Akses Tanggal 08 November 2015

[2] Prof. Dr. Mohammad Nasir, Ph.D, 2015, Simposium Nasional Akuntansi SNA XVIII, Medan, 16-19 September 2015

[3] Badan Akreditasi Nasional Perguruan Tinggi, Buku 1 Naskah Akademik, 2009, Jakarta [4] Achmad Solihin, Zainal A. Hasibuan,2012,Pemodelan Arsitektur Teknologi Informasi Berbasis Cloudcomputing untuk Institusi Perguruan Tinggi, Prosiding Seminar Nasional Teknologi Informasi dan Komunikasi Terapan, Semarang 23 Juni 2012

[5] Tim Pengembang SPMI Ditjen Dikti, Kemdikbud, Kebijakan Nasional Sistem Penjaminan Mutu Eksternal atau Akreditasi, Kementerian Pendidikan dan Kebudayaan Republik Indonesia, Direktorat Jenderal Pendidikan Tinggi-Direktorat Pembelajaran dan Kamahasiswaan, September 2014. Jakarta

[6] Tim Akreditasi BAN-PT, Asesmen Kecukuptan, Akreditasi Institusi Perguruan Tinggi Tahap I Tahun 2014, Badan Akreditasi Nasional Perguruan Tinggi, 2014, Yogyakarta

[7] Tim Akreditasi BAN-PT : Akreditasi Institusi Perguruan Tinggi (AIPT), Badan Akreditasi Nasional Perguruan Tinggi 